\title{
Increasing HOTS of High School Students Using Mobile Technology and Scaffolding Approach: A Study on Physics Learning
}

\author{
Singgih Hutomo Aji ${ }^{1(*)}$, Suparno ${ }^{2}$ \\ ${ }^{1,2}$ Faculty of Mathematics and Science, Universitas Negeri Yogyakarta
}

\begin{abstract}
Received: October 31, 2020 This study aims to develop an Android-based learning media application Revised: December 22, 2020 on simple harmonic motion physics material and is used to improve the Accepted: January 8, 2021 HOTS ability of students by learning using the scaffolding approach. This study is an R\&D with a 4D model consisting of the Defining, Designing, Developing, and Disseminating stages. The operational test at the Developing stage was carried out using an experiment with the PretestPosttest Control Group design. The product in this study is an Androidbased physics learning media application on simple harmonic motion material that has been tested for its feasibility for use in physics learning. Then, the product was tested in the field by being implemented in learning. The experimental results in the experimental class using android media and the scaffolding approach and the control class using conventional learning showed a significant difference in HOTS abilities. The implementation of Android-based physics mobile learning media and the scaffolding learning approach has a positive effect on the HOTS ability of students.
\end{abstract}

Keywords: physics, mobile learning, scaffolding, HOTS

(*) Corresponding Author: $\quad$ singgihhutomo@yahoo.com Phone: +62 85786292200

How to Cite: Aji, S.H. \& Suparno, S. (2020). Increasing HOTS of high school students using mobile technology and scaffolding approach: A study on physics learning. Jurnal Teknologi Pendidikan, 22 (3): 182-199. http://dx.doi.org/10.21009/itp.v22i3.17845

\section{INTRODUCTION}

The Indonesian nation is in a very crucial position, which is facing a population demographic bonus. The year 2028 is predicted to be the year when the effects of the demographic bonus will begin to be felt (Arieputri, 2020). However, it really needs to be prepared as well as possible so that the population of productive age at the time the demographic bonus takes place really has ideal quality (Subandowo, 2017). Whereas, the facts show that the ability of Indonesian students in terms of science, numerical and reading performance is still below the global average (OECD, 2016). Furthermore, the innovation capability of the Indonesian nation according to the Global Innovation Index is still at 85th place out of 129 countries (WIPO, 2019). This of course must be improved, given that the abundant number of productive age population, if not properly prepared, may even be the cause of enormous losses. Therefore, the steps taken in shaping human resources at this time will be the determinants of success in the future. A human competency framework that can be used as a reference for good human resources, one of which is contained in the 21 st century skills framework. In this framework, individuals are required to have several skill sets, one of which is learning and innovation skills which are packaged in $4 \mathrm{C}$, namely critical thinking, collaboration, communication, and creativity (P21: Partnership for 21st Century Learning, 2007). If analyzed, the skills that are considered in the framework of 
these ideas are part of higher-order thinking skills (Nofrion \& Wijayanto, 2018; Retnawati et al., 2018). High-order thinking skills (HOTS) can be interpreted as the ability to think about and use what has been learned, the ability to judge something wisely and provide rational criticism, and the ability to solve problems that cannot be solved just by remembering (Brookhart, 2010). Individuals with good HOTS tend to have higher learning achievement and experience a more positive learning process (Ramos et al., 2013; Tanujaya et al., 2017). HOTS is needed to solve a variety of complex problems and unusual situations (Voogt \& Roblin, 2012). This is in line with the facts of changing times which increasingly expose people to increasingly diverse situations. It is inevitable that this ability has become a basic skill that must be mastered by individuals around the world to be able to compete. In this era, humans are required to not only have a strong back, but also a strong mind to work.

Efforts that can be made as a preparation for the arrival of the demographic bonus and improving the quality of the individual in general can be applied in the world of education (Arieputri, 2020; Maryati, 2015). The target achievement in learning in schools at this time should have reached a high level of cognition. Learning activities in schools should be able to facilitate students to practice HOTS. Physics as a subject in school can be an option to facilitate students in training their thinking skills. Given that the subject of physics is included in science, which is closely related to the scientific method, so ideally it should be able to encourage students to apply scientific values and be able to encourage them to think. Physics learning should not be just an activity to transfer teacher knowledge to students, but must go through a process that involves students to think actively so that their understanding becomes good (Nisrina et al., 2018). This active activity is an opportunity to practice their thinking skills, especially higher-order thinking skills. Several attempts can be made to achieve learning that involves students, or what is known in the curriculum as student-centered learning. This is one part of the learning principles formulated in the 2013 Curriculum.

In addition to changing the teacher's paradigm in creating a learning center, the curriculum also mandates changes in finding learning sources, from previously being one source to multiple sources. This is certainly not difficult to implement because with the advancing times, information exchange becomes easier, so that learning resources become more varied and easier to access. One of the interesting options is mobile technology in learning or mobile learning. Mobile learning is a part of e-learning that specifically utilizes information and communication technology products that are mobile, in this case a smartphone or tablet computer. Mobile learning is learning that uses portable and mobile devices as a medium to facilitate learning (Martono \& Nurhayati, 2014). Smartphones are used as e-learning tools that allow convenience in helping students complete their assignments and learning activities anywhere, both outside and inside the classroom. (Matsun et al., 2018; Yi et al., 2016). The use of mobile smartphones as learning media has great potential to be developed because among other ICT products, mobile devices are the fastest growing products (Taufiq et al., 2016). More specifically, mobile devices with the most potential are gadgets with the Android operating system, because compared to similar products, Android is the most widely used operating system (Zahid, 2018). Moreover, the existence of smartphone technology has become a characteristic of today's young generation, including high school students (Subandowo, 2017). Smartphones with various features in them, if used properly, can help students learn (Anshari et al., 2017; Tossell et al., 2015). Android itself already has an interactive nature in it, so that Android smartphonebased learning media can be made interactive. Thus, students can interact and adjust media use in two directions according to their respective preferences. The use of interactive multimedia can arouse students' learning motivation, stimulate curiosity, so that it can build 
a fun and not boring learning atmosphere. (Hochberg et al., 2018; Oprea \& Miron, 2014; Urban-woldron, 2009).

Furthermore, efforts to increase the achievement of students through learning activities can also be achieved with the right approach and in accordance with the principles of learning. The 2013 curriculum has described that learning carried out in the classroom is an activity of students to construct their understanding through a cognitive process. In line with this, efforts to increase learning achievement and thinking skills of students can be carried out based on the social constructivism theory developed by Vygotsky. Zone of proximal development (ZPD) is a term used by Vygotsky to describe the area of a child's actual ability at the lower limit to the potential ability at the upper limit (Santrock, 2017; Schunk, 2011). This potential ability can be achieved with the help of a teacher or a more skilled peer. This assistance can be provided in the form of scaffolding. Vygotsky believes that learning is most effective when children are in their ZPD (Slavin, 2017). In the scaffolding approach assistance is reduced during the learning process (Santrock, 2017). The assistance provided is adjusted to the abilities of students. The main feature that distinguishes scaffolding from other forms of learning aids is that temporary assistance is provided when students face problems (Belland, 2017). Scaffolding in learning can serve as an aid, a tool, expanding the range of learning, and achieving difficult tasks (Schunk, 2011). This approach helps students solve problems and improve critical thinking skills (Helmi et al., 2017; Lin \& Singh, 2015; Rusli et al., 2014). Belland (2017) proves that scaffolding can increase the deepening of learning content, strengthen motivation, and increase HOTS. In this study, the scaffolding learning approach used is the scaffolding structured into three levels, namely a) environment provision, b) explaining, reviewing, and restructuring, and c) developing conceptual understanding (Anghileri, 2006).

Starting from this explanation, the researcher designed and implemented a series of efforts to improve higher-order thinking skills using mobile technology facilities and learning scaffolding strategies. Therefore, the aim of this study is to develop Android-based physics learning media. The content of the media consists of teaching materials, discussion materials, question exercises, and HOTS-oriented evaluation systems in physics materials. In addition, this study also implements the use of android media in learning with a scaffolding approach to find out how effective these efforts are in increasing students' HOTS.

\section{METHODS}

This study was a research and development using a 4D development model (Thiagarajan et al., 1974). This model consists of the Defining, Designing, Developing, and Disseminating stages. The detail of each stages of the research are showed at Figure 1. Implementation testing of the developed media products is carried out at the Developing stage with a pretest-posttest control group design as shown in Table 1. Symbol O1 is pretest and $\mathrm{O} 2$ is post-test for both classes, while $\mathrm{X} 1$ is class using the developed learning media and X2 is class using standard material (ppt or pdf files). Data collection was carried out using the HOTS question instrument that had been developed. The pretest was carried out at the beginning of the lesson to measure the students' initial abilities, then the posttest was carried out at the end after the students received learning according to the treatment of each class. 


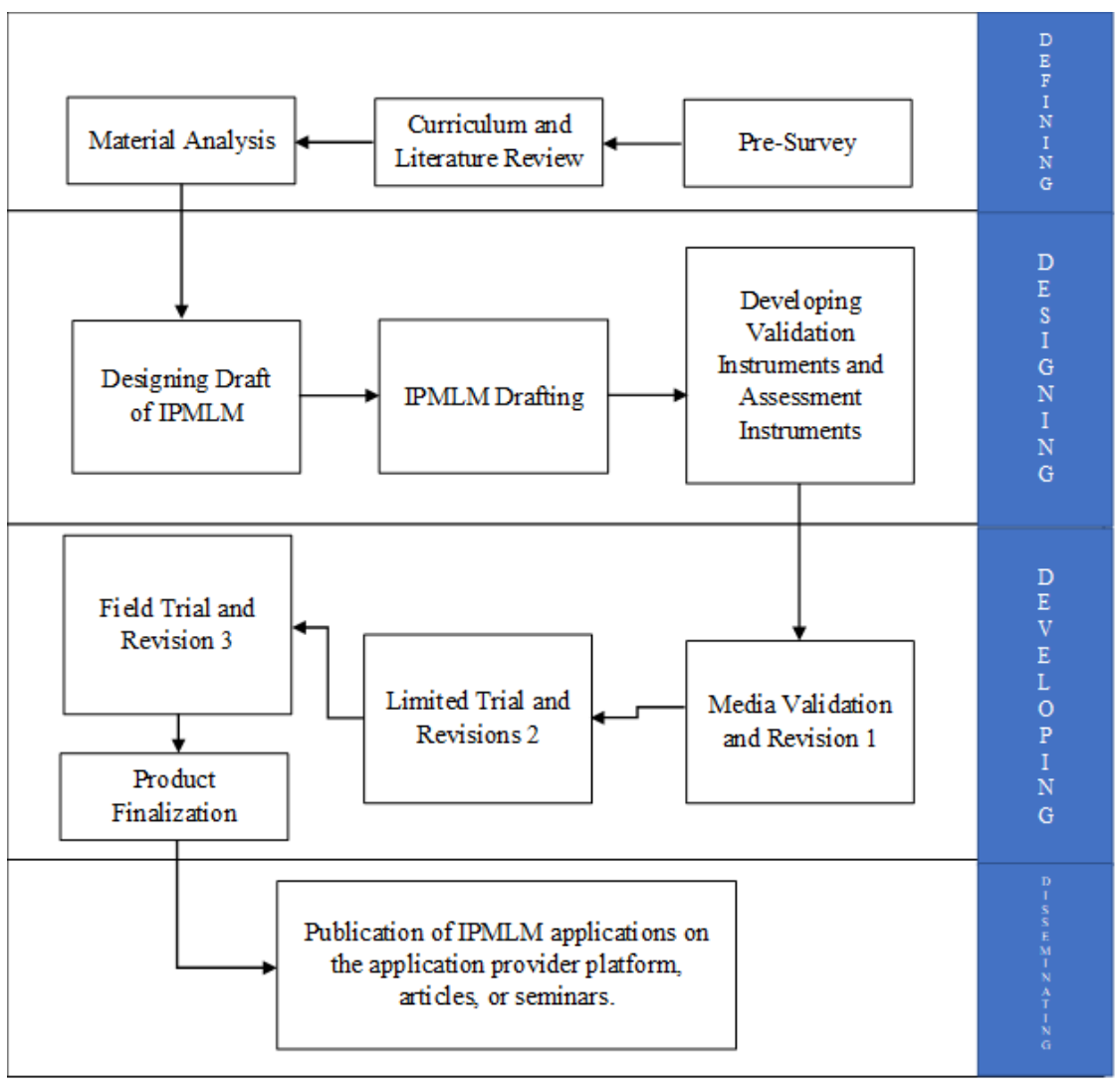

Figure 1. 4D Model Development Procedure

The research was conducted by involving students in 3 high schools in Banyumas district namely, SMA N 1 Purwokerto, SMA N 2 Purwokerto, and SMA N Sokaraja. This research was carried out in Banyumas Regency, Central Java Province, Republic of Indonesia. However, experimental activities were carried out online or distance learning due to the pandemic which caused the closure of schools and the elimination of face-toface learning activities. As for the process, learning is carried out using digital tools that are familiar to both teachers and students, namely WhatsApp and Google Classroom. The two platforms were chosen to suit the conditions of the school and students. Previously, the school had also conducted a study on distance learning facilities that were suitable for their students. The learning process also follows the directions from the teacher to match what has become the habit of the teacher. This is done as an effort to create learning activities that are in accordance with the character and conditions of students, in order to create maximum learning (Herliandry et al., 2020). In addition, the facts in the field also show that many students feel burdened during the distance learning process, adjustments are also made so that students do not feel their burden of learning increases.

Table 1. Pretest-Posttest Control Group Design

\begin{tabular}{llll}
\hline Class & Pre-test & Treatment & Post-test \\
\hline Experiment & $\mathrm{O}_{1}$ & $\mathrm{X}_{1}$ & $\mathrm{O}_{2}$ \\
Control & $\mathrm{O}_{1}$ & $\mathrm{X}_{2}$ & $\mathrm{O}_{2}$ \\
\hline
\end{tabular}

The results of the IPMLM product feasibility assessment and curiosity questionnaire were analyzed using descriptive analysis. The average score on each aspect of the appraisal of the feasibility of learning media was converted to a scale of five by using scale showed on Table 2 . 
Table 2. Five Scale Assessment Criteria

\begin{tabular}{ccc}
\hline \multicolumn{2}{c}{ Respondent Score } & Category \\
\hline $\mathrm{X}_{\mathrm{i}}+0,6 \mathrm{SB}_{\mathrm{i}}<\mathrm{X}$ & Very Good \\
$\mathrm{X}_{\mathrm{i}}+0,6 \mathrm{SB}_{\mathrm{i}}<\mathrm{X}<\mathrm{X}_{\mathrm{i}}+1,8 \mathrm{SB}_{\mathrm{i}}$ & Good \\
$\mathrm{X}_{\mathrm{i}}-0,6 \mathrm{SB}_{\mathrm{i}}<\mathrm{X}<\mathrm{X}_{\mathrm{i}}+0,6 \mathrm{SB}_{\mathrm{i}}$ & Respectably good \\
$\mathrm{X}_{\mathrm{i}}-1,8 \mathrm{SB}_{\mathrm{i}}<\mathrm{X}<\mathrm{X}_{\mathrm{i}}-0,6 \mathrm{SB}_{\mathrm{i}}$ & Not Good \\
$\mathrm{X}<\mathrm{X}_{\mathrm{i}}-1,8 \mathrm{SB}_{\mathrm{i}}$ & Bad \\
\hline \multicolumn{2}{l}{ Information: } \\
$\mathrm{X}_{\mathrm{i}}$ & $:$ mean ideal = $1 / 2$ (maximum score ideal + minimum score Ideal) \\
$\mathrm{SB}_{\mathrm{i}}$ & $:$ mean deviation ideal = $1 / 6$ (maximum score ideal - minimum score Ideal)
\end{tabular}

Before being used to measure, the HOTS instrument was validated to find out whether each item had followed good construction rules. Furthermore, the questions were tested empirically to determine the items fit of IRT model. Data analysis of the empirical test of questions was carried out using the QUEST computer program. Finally, experimental data in the control class and experimental class were analyzed using parametric statistics with the help of the SPSS program. The analysis was carried out on the differences in HOTS abilities of students in the control and experimental classes, as well as differences in HOTS abilities before and after learning in each class.

\section{RESULTS \& DISCUSSION}

\section{Results}

\section{Defining Stage}

At this stage, a preliminary study was carried out with field study activities and literature studies. Field studies were carried out in 3 schools in Banyumas district, Central Java through observation and interviews. The results from the field are then used as materials for analyzing the curriculum and students. The entire school has used the 2013 Curriculum. Then from the students, it is known that all students have their own personal cellphones, but not all of them are phones with the Android operating system. However, there were a few students with non-android cellphones in each class, around less than $10 \%$. The existence of cellphones in schools is not a problem because the three schools do not implement a ban on bringing cellphones to school. It is known that learning activities have not specifically made use of students' personal cellphone use. The involvement of cell phones in new learning is limited to helping or complementing, and even then, it is very rare. Thus, the potential for the use of personal cell phones, especially Android smart phones as a medium of learning is very wide open. The use of Android-based learning media can be an innovative step and add options for learning resources that can be used, in accordance with learning principles that encourage the use of various learning resources. Furthermore, the implementation process no longer requires the procurement of tools because cell phones have become a common need among students.

Adaptation of research activities to be implemented in distance learning conditions due to pandemics was also carried out, although it followed, because the pandemic situation in Indonesia began when research was at the development stage. The results of observations, interviews, and discussions with the school both through the vice principal, teachers, and students indicate that research activities must be carried out using the online method. Possible facilities to use are the WhatsApp and Google Classroom platforms. The 
use of more complicated facilities such as video conferencing cannot be done due to conditions that are not yet possible. Even though it is forced to do learning with video conferencing, there will be gaps between students because not all students can take part in the learning. The study conducted by the school also found that the use of learning facilities that were too complicated, such as the need for gadget specifications that were too high and the need for too much internet quota, were the main obstacles. Given that not all students can be equal to one standard of ability to have gadgets and an internet connection

\section{Designing Stage}

Media designs and designs are made at this stage. The design begins by making a flowchart showing what features will be embedded in the media. Making flowcharts also facilitates the design process so that the media created has a logical flow. Next, a media storyboard is created that shows what the media will have. The storyboard explains in more detail what is in the application including button placement, size, proportion, object placement, to colors and fonts. The layout designed in the storyboard includes the splash screen, main menu, directions for use, competencies, list of materials, content, discussion, evaluation entry screen, evaluation, and developer profile. At this stage a feasibility sheet is also prepared which will be used by the assessor to assess the feasibility of the media product produced.

The HOTS measuring instrument is also designed at this stage. The design of the instrument is made in the form of a question grid which is derived from the indicators of learning achievement. The questions were designed to be oriented towards the HOTS C4 and $\mathrm{C} 5$ cognitive domains. The HOTS question is in the form of multiple-choice reasons with five choices of answers and five reasons for each. Planning the instrument was also followed by the creation of a feasibility sheet that would be used to assess the validity of the instrument at a later stage.

\section{Developing Stage}

At this stage, all planning in the previous stage is carried out. The media is made in accordance with the existing appearance on the storyboard followed by the activation of features in the navigation function and the interactions therein. The appearance of the developed media product is presented in Figure 2 to Figure 8.

The earliest displays of media were the splash screen and identification input. This section displays the media identity with the splash or welcome screen commonly embedded in mobile applications. Furthermore, when the application is run for the first time, a display will appear to enter the user's identity. This feature serves as an identity that is stored attached to the smartphone storage. In addition, after the user enters the identity and presses the save button, the application will send the data to Google Sheets. The sending of identity functions so that researchers can monitor students who have successfully installed and run the application. The main menu display is the layout that appears after the splash screen animation is complete. This activity contains the entire navigation button for the features contained in the application. The buttons in the main menu are the competency, material, evaluation, instructions, developer profile, and exit buttons. Each of these buttons will lead to another display according to its name. The main menu will also display the name according to the identity that was entered in the identity form when the application was first run. The main menu view of IPMLM is shown in Figure 2. Help activities are accessed via the help button at the bottom of the application on the main menu. The instructions display will begin with a welcome slide, and then contain a view of the application with a description of each navigation element in it. Help consists of several slides which can be 
navigated using the navigation keys at the bottom or shifted right and left. Figure 3 . is a display of the help screen.

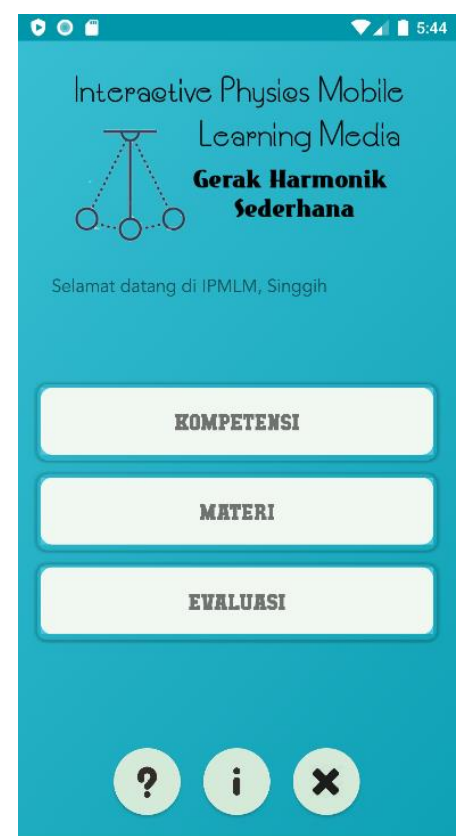

Figure 2. Main menu of IPMLM

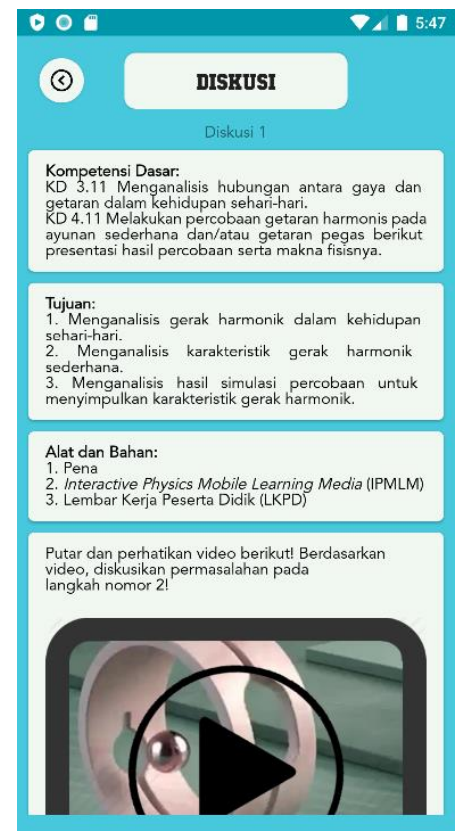

Figure 4. Layout of discussion material consisted of basic competencies, discussion goals, tools of materials, videos, and simulations.

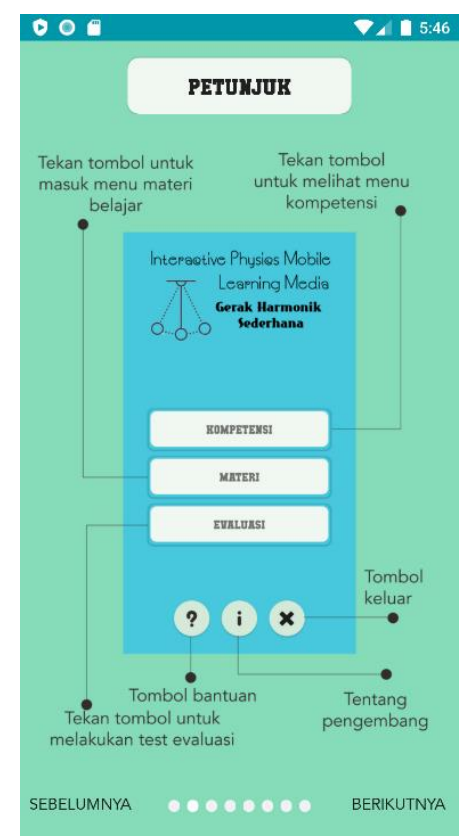

Figure 3. Help feature gave information of button and navigation embedded inside the application

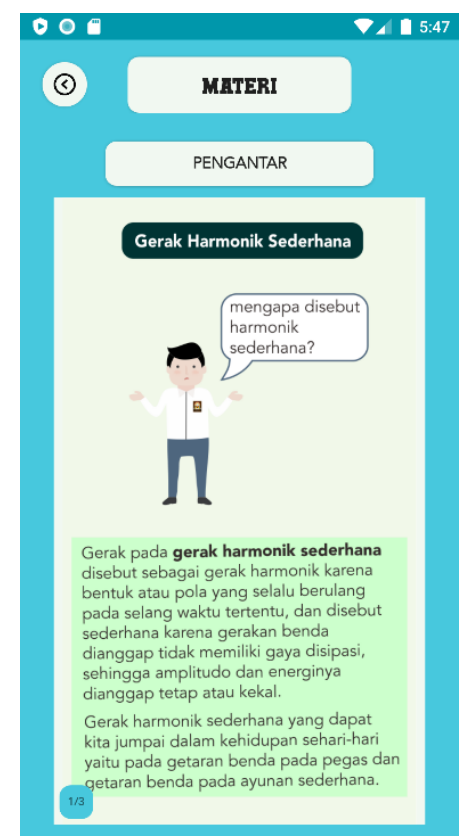

Figure 5. The layout of material displaying physics content sub material Introduction of simple harmonic motion 
The material menu is arguably the densest layout in the application. In this section, there are navigation buttons that lead to sub-material, discussion materials, and formative tests. If one of the sub-materials is pressed, the user will be directed to the content of the pressed sub-material. The content of the material is displayed with slides. Users can read the material by sliding to the right and left on the contents of the material as shown in Figure 5. At the bottom left, the number of slides and the position of the slides being displayed is also displayed. This type of layout is similar to that used in Facebook's Instagram application. Students who are accustomed to using social media are certainly familiar with this type of navigation. Furthermore, when the user presses the discussion button, it will be directed to a display like Figure 4 . This feature displays basic competencies, objectives, tools and materials, as well as discussion materials in the form of videos and simulations. Another menu option in the material menu is the formative test. In the formative test, users will be presented with a choice of question packages. This display will also display a description of whether the user has done the test or not. If the user has done the test, the score obtained will be displayed and the user can also access the item solution discussions of each item that has been done. Discussion of questions displays the completion steps of each item along with the correct answer. In addition, the item solution discussion section also displays the score of each item obtained by students. The display of the question discussion feature is presented in Figure 6.

Evaluation activities contain evaluation questions that can be done by users after being given instructions by the teacher. This activity is protected with a code so that students do not try before it's time to work. Furthermore, after the code is entered and the user can enter, students are directed to the choice of question packages. The contents on the display of the question package options are the same as those in the formative test, namely there is a description of the work status and also a discussion button. If the student has selected one of the question packages, a confirmation display to start along with evaluation instructions will be displayed. If students press the start button, the test will begin immediately displaying the questions. The display of the test contents is shown in Figure 7. The test is equipped with a countdown timer at the bottom of the layout. If the time runs out, the test form will be closed automatically, and the answers will be saved. In addition to automatically, users can also complete the test before the time runs out by pressing the finish button on the bottom right. When a test is declared completed either manually or automatically due to timeout, answers will be sent to an evaluation spreadsheet. In this recording application, an internet connection is required. The application works by making Google Sheets the back end, in this case to accommodate student evaluation activity data. This spreadsheet accommodates all the answers of students who use the application for both formative test answers and answers to the final evaluation. The data in the spreadsheet is differentiated using question codes.

At this stage the media also has improvements to errors or bugs and features improvements based on what is found in the field or suggestions from the assessors. Some of the improvements made during this stage include: 1) reducing the size of the application file; 2) fixed some unreadable layouts on phones with small screens; 3) added the submit identity feature to find out students who have successfully installed and run the application; 4) improved coding in the evaluation system; 5) correcting inappropriate material sequences; 6) Change the target android API to the latest version. 


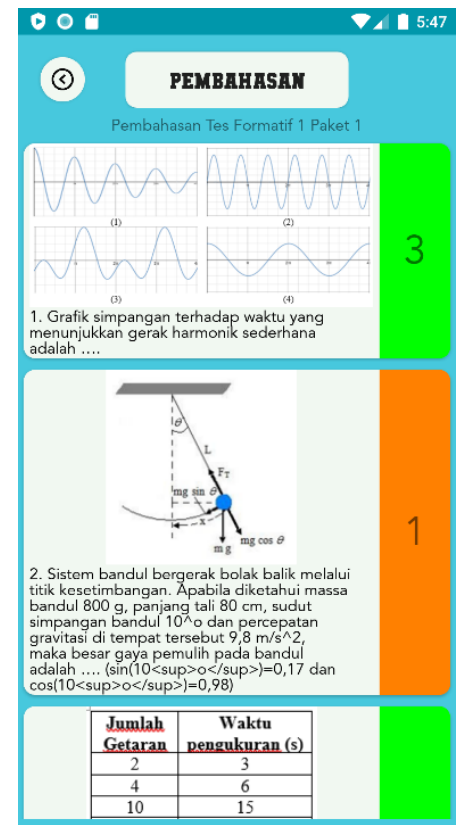

Figure 6. The question discussion view displays the score of each item that has been worked on as well as the completion of that item.

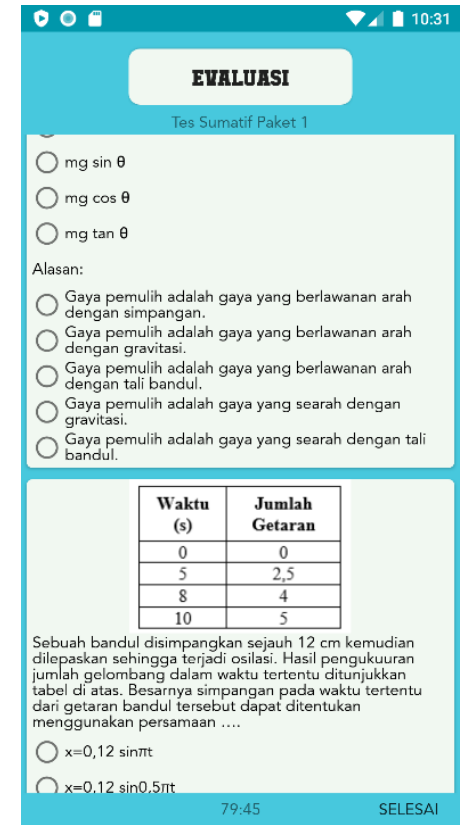

Figure 7. The display of evaluation test showing two tier HOTS test items.

\section{Validation of Media Product}

The feasibility test of the IPMLM media application is carried out based on the judgment of experts and practitioners. The assessment is carried out on the aspects of software engineering, visual communication, ease and flexibility of access, learning, and materials. The results of the media feasibility assessment are presented in Table 3. Based on the results of the assessment, it can be concluded that the IPMLM media on Simple Harmonic Motion material is declared feasible and can be used in learning activities. The media got a very good assessment with an average score of 95.5 .

Table 3. Media Feasibility Score

\begin{tabular}{ccc}
\hline Aspects & Score & Category \\
\hline Software Engineering & 94.0 & Very Good \\
Visual Communication & 97.1 & Very Good \\
Ease and Flexibility of Access & 97.5 & Very Good \\
Learning & 95.0 & Very Good \\
Material & 94.0 & Very Good \\
\hline Average & 95.5 & Very Good \\
\hline
\end{tabular}

\section{Readability Test of Media Product}

The media was tested on a limited basis to a number of randomly selected students, on the condition that students involved in this test must have an Android phone. Random testing is carried out so that the test is able to detect if there are certain types of smartphone that cannot be installed or can be installed with media applications but experience errors. Such detection can be useful for evaluating and improving the level of support for application device types. This test is carried out using a readability questionnaire given to 
students after they have installed and used the media application on their respective smartphones. The assessments carried out were on the aspects of content, graphic, presentation, and language. While the number of students involved was 27 people. Limited test results data on the media are presented in Table 4.

Table 4. Limited Readability Test Score

\begin{tabular}{ccc}
\hline Aspects & Score & Category \\
\hline Content & 73.1 & Good \\
Graphic & 74.5 & Good \\
Presentation & 76.7 & Good \\
Language & 74.1 & Good \\
\hline Average & 74.6 & Good \\
\hline
\end{tabular}

\section{Validation of HOTS Question Instruments}

Before being used to measure students' HOTS abilities during the study, HOTS instruments were first validated by experts and practitioners. All items in the two question packages were validated with a total of 5 assessors. The validation was carried out using a HOTS item assessment questionnaire which consisted of several criteria. The results of the assessment for each item are written on a scale of 4 levels with a minimum score of 1 and a maximum of 4 . The assessment of the validity of each item is then analyzed using the Aiken's $\mathrm{V}$ index, namely by looking for the $\mathrm{V}$ index value from the results of the assessment of each item. The index $\mathrm{V}$ of each item is then compared with the minimum value listed in the Aiken table. In the Aiken table, for 5 raters and a scale of 4 has a minimum $\mathrm{V}$ index value of 0.93 in order to these items can be declared valid (Aiken, 1985). Thus, valid items are items that have an index V not less than 0.93. Based on the results of the validator's assessment of the HOTS instrument, it was found that all items met the valid criteria. The smallest $\mathrm{V}$ index obtained is 0.93 so that it still meets the minimum criteria of index $\mathrm{V}$ in the table.

\section{Empirical Test of HOTS Question Instruments}

After passing the validation of the contents and construction of HOTS items, the question instruments were also tested to be done by students. This test is conducted to determine the validity of the questions empirically. The test results were then analyzed using the modern test theory or Items Response Theory (IRT) using the QUEST computer program. The results of the QUEST program output analysis used as an indicator of the feasibility of the questions were whether the items tested were fit to the Rasch model. Valid items are items that have an MNSQ Infit value ranging from 0.77 to 1.30 (Hambleton et al., 1991). The test results of the HOTS instrument in this study indicate that all items in the two question packages are fit with the Rasch model, with the smallest MNSQ infit value 0.80 and the largest 1.28. The output of the QUEST program for the fit model section is shown in Figure 8. Thus, all items on the HOTS instrument can be declared valid both theoretically and empirically. 


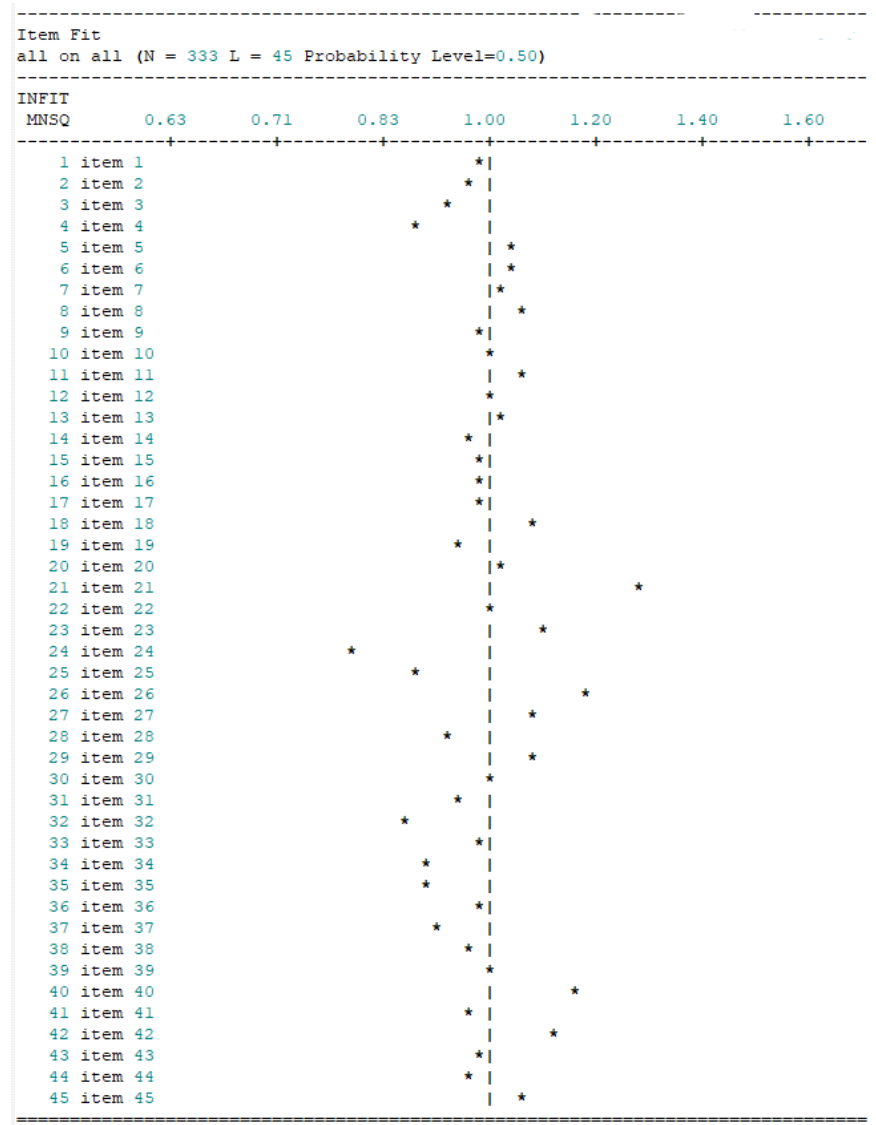

Figure 8. HOTS Instrument Item Fit Analysis

\section{HOTS Difference Test in Experimental and Control Class}

The HOTS ability of students after participating in learning using Android-based media IPMLM and scaffolding learning approaches were tested against the HOTS abilities of students who did not use mobile learning applications and scaffolding approaches (conventional). Testing was carried out using One Way ANOVA analysis to determine whether there was a significant difference in mean between the experimental class and the control class. The analysis was carried out by first doing the assumption test for normality and homogeneity of the data. The prerequisite test results show that the data meets the criteria for normal distribution and homogeneity, so that the data can be continued for analysis. The ANOVA test of the HOTS ability data of students is shown in Table 5. From the results of the analysis, it can be concluded that at the 5\% confidence level there is a significant difference in the HOTS ability of students who have taken physics learning using IPMLM android-based media and scaffolding learning approaches.

Table 5. ANOVA Analysis Result

\section{ANOVA}

\begin{tabular}{cccccc}
\hline & Sum of Squares & df & Mean Square & F & Sig. \\
\hline Between Groups & 22.662 & 1 & 22.662 & 9.790 & 0.002 \\
Within Groups & 270.844 & 117 & 2.315 & & \\
Total & 293.506 & 118 & & & \\
\hline
\end{tabular}




\section{HOTS Improvement in Experimental and Control Class}

After it is known that HOTS abilities in the experimental and control classes are significantly different, then an analysis is carried out on the increase in HOTS in each of these classes. The test was carried out by comparing the HOTS abilities of students before taking part in learning or pretest scores and after participating in learning or posttest scores. Analysis of the data was carried out using Paired Samples T Test analysis in the SPSS program. The analysis results for the two classes are presented in Table 6 below. In the table, it is shown that the significance value for both the control and experimental classes is $<0.05$. Thus, it can be concluded that both the control class and the experimental class experienced a significant difference between HOTS abilities before learning and after learning. The mean difference in the experimental class is 2.55 and the mean difference in the control class is 1.61 , at a maximum score of 10 . Hence, if measured from the difference in mean, it can be seen that the experimental class learning using Android-based IPMLM media and scaffolding learning approaches have better increased HOTS ability.

Table 6. Paired Samples T Test Analysis Result

\begin{tabular}{cccccc}
\hline \multicolumn{6}{c}{ Paired Differences } \\
\hline Mean & $\begin{array}{c}\text { Std. } \\
\text { Deviation }\end{array}$ & t & df & $\begin{array}{c}\text { Sig. (2- } \\
\text { tailed) }\end{array}$ \\
\hline Experimental Group & -2.55207 & 1.39941 & -13.889 & 57 & 0.000 \\
Control Group & -1.61951 & 1.28473 & -9.845 & 60 & 0.000 \\
\hline
\end{tabular}

\section{HOTS Profile Before and After Learning}

HOTS ability of students before and after learning proved to experience significant changes. In addition, the HOTS abilities of students in the experimental and control groups also differed significantly. This is supported by data that shows the existence of different HOTS ability profiles before and after learning both in the control and experimental groups. The HOTS abilities of students are mapped on a scale of 5 categories, which consists of: very low, low, fair, good, very good. The HOTS ability profile before and after learning in the control and experimental classes is shown in graphical form in Figure 9. In the experimental class, which has a higher average HOTS score increase, has $15.5 \%$ of students with very low HOTS ability, $81 \%$ students with low ability, and $3.4 \%$ with fair ability before learning. Then after participating in learning using IPMLM learning media and the scaffolding approach, it increased to $27.6 \%$ of students having low abilities, $48.3 \%$ of students having fair abilities, $13.8 \%$ of students having high abilities, and $10.3 \%$ of having very high abilities. This data clearly shows a significant increase as in the previous analysis, because from previously more than $95 \%$ of students had low HOTS abilities or below, to $27.6 \%$ who still had low HOTS abilities after learning. Whereas in the control class, before learning activities, there were $4.9 \%$ students with very low abilities, and $95.1 \%$ students with low abilities. Then after participating in learning with conventional media and learning approaches, it has increased to $47.5 \%$ of students having low abilities, $42.6 \%$ of students having fair abilities, and $9.8 \%$ of students having high abilities. However, although there was also a significant increase in the average HOTS score, when compared to the experimental class, in this class none of the students had HOTS abilities at very high criteria, and almost half or $47.5 \%$ of the students were still in the low ability category. Thus, it can also be seen from the profiles of students in the two classes that the implementation 
of Android-based learning media IPMLM and scaffolding learning approaches are not only able to increase the average HOTS score, but also increase the HOTS ability criteria of students. The data show that the treatment is able to encourage better learning achievement, in this case it is in the HOTS domain. However, it needs to be admitted that the increase has not been maximal because there are still students who have low HOTS abilities, then when viewed from the average, it is not yet good either. This is most likely due to learning activities that were still being carried out remotely or online at the time the research was conducted. As admitted by the teacher, at the time of the interview, the teacher admitted that when learning was not carried out face-to-face, it was more difficult to control students. This has an impact on learning achievement that is less than optimal when compared to face-to-face learning.

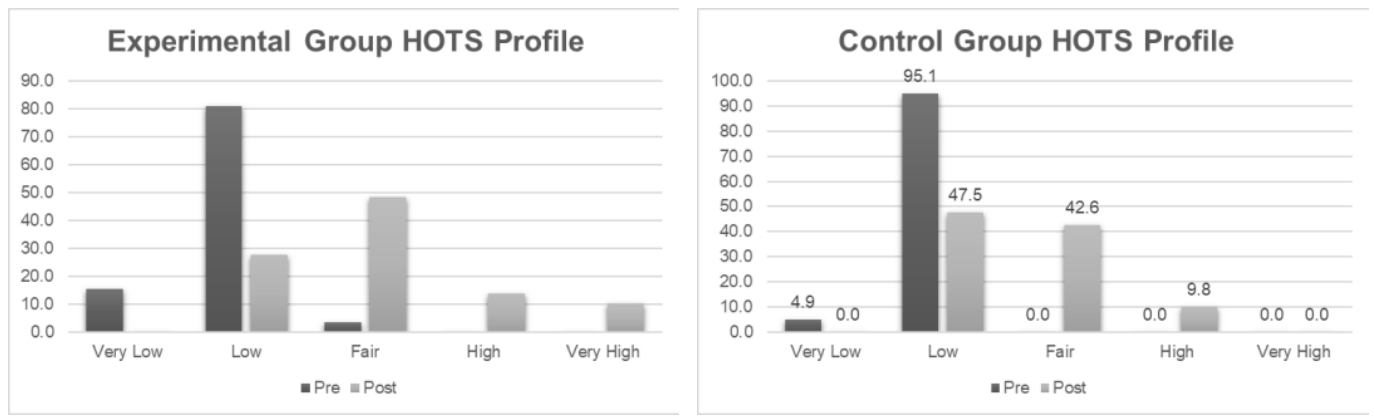

Figure 9. HOTS Profile Graph

The overall results of the analysis show that there are findings of positive effects from the use of mobile learning media and the scaffolding learning approach. These results support the results of previous research on the implementation of scaffolding (Andi \& Handayani, 2015; Helmi et al., 2017; Rusli et al., 2014), and also mobile learning media (Agustihana \& Suparno, 2018; Kuhn \& Vogt, 2015; Lee, 2015; Mardiana \& Kuswanto, 2017; Taufik \& Kristanto, 2018). Scaffolding has been proven to be able to have a positive influence on the learning process of students. The use of scaffolding in learning can take various forms. In this study, scaffolding is applied in learning through learning steps controlled by the teacher. The IPMLM application also plays a role in the scaffolding process of students which is packaged in the form of an android application. This can be said as an implementation of learning scaffolding in the form of e-scaffolding (Saman et al., 2017). One of the features in the IPMLM application is that students have the opportunity to do test questions more than once because the application is equipped with more than one question package. Therefore, in the process, students work on a package of questions then access the discussion of each item if they experience problems with certain items. After going through the process, they can then work on another package of questions after they have succeeded in finding a solution to the problems they faced while working on the first package of questions. This activity can also be monitored directly by the teacher because every answer that students make is entered into the online teacher's spreadsheet data. With this system, teachers can find out more specifically the problems faced by students. Detection of this problem becomes very important because in learning scaffolding, feedback or assistance is given to students when students have problems (Belland, 2017). Appropriate scaffolding can be provided by the teacher, either directly or through ICT-based media when students' problems are known, for example through detection of misconceptions (Lee, 2010). So, giving scaffolding will be better if in the process scaffolding is not only emphasized through teacher directions, but also involves media applications which have the role of providing scaffolding to students interactively according to the needs of each student. 
The scaffolding process at each level is achieved using different methods. Level 1 (environment provision) is carried out by creating a learning situation that is comfortable and does not overwhelm students. The teacher provides clear learning instructions and provides opportunities for students to ask questions or difficulties. This process is supported by an IPMLM media application that is comfortable to use with an attractive design and is not boring. Applications are also on devices that are close to them, namely the smartphone devices they use every day. Furthermore, the learning material in the media is designed with sub-sections that are divided into small topics so that students can more freely understand the material and are not overwhelmed by seeing too many texts at one time. Level 2 (explaining, reviewing and restructuring) is done by inviting students to actively develop their thinking and understanding. Students carry out this activity with the help of stimuli from discussion worksheets and discussion activities in groups. In discussion activities, students use the discussion feature on the IPMLM application which is equipped with videos and simulations. Students conduct analysis and evaluation of discussion materials with the final result being able to conclude after passing this activity. The interactive nature of the IPMLM application based on android also supports freedom of control, so that students can adjust media usage according to their respective learning speeds. This facilitates the process of students in reviewing and restructuring. Level 3 (developing conceptual) is carried out by developing the understanding that has been obtained in the previous stage by evaluating the results of the discussions that have been carried out, the teacher provides feedback on what students have obtained in the discussion process so that students rectify if there is a misunderstanding and strengthen correct understanding. This process is also supported by questions oriented to the process of analyzing and evaluating, so that students can practice HOTS skills and develop a broader understanding through the problems presented in the questions. In IPMLM, students also have the opportunity to work on more than one question package, so that they have time to learn and develop understanding after completing a package of questions, then they can continue to work on another package of questions.

Discussing mobile learning, in general, with all of its advantages can provide benefits and positive effects on student learning performance. However, it cannot be denied that behind all of that, the use of smartphones without specific consent and clear directions can actually be a source of interference (Anshari et al., 2017). Therefore, at least, if a smartphone is to be used as a learning support tool, ideally a "container" with a clear construction and purpose has been prepared, in this study is the IPMLM. Smartphones used in learning without a clear purpose and specifically designed will actually make students less likely to benefit from their use (Woodcock et al., 2012). However, apart from this, the world of education in 2020 which is predominantly carried out using distance learning methods in various regions in Indonesia because of the COVID-19 pandemic situation, will clearly benefit from the implementation of smartphones. This happens because the learning process is completely dependent on the gadgets owned by each student. Therefore, if a special preparation is made to design a smartphone-based learning support media, it will certainly have a better effect than if it is not done at all. Because in the end, whether there is a special smartphone-based media or not, learning activities during the pandemic are still have to be done remotely, and of course using a smartphone or similar technology. Furthermore, the nature of mobile technology, in this case the smartphone itself has the advantage of flexibility in use, so that learning applications based on mobile devices become multimedia that can be opened anytime and anywhere. (González et al., 2015; Martono \& Nurhayati, 2014). Moreover, the IPMLM android application is offline so it does not depend on an internet connection. This opens up opportunities where when students are outside the reach of wi-fi and don't have internet data quota, they can still open the application and study material and do practice questions. The weakness of the IPMLM 
application, if it is not connected to the internet, is only in the feature of sending answers to test questions, because to be able to send answers to the teacher's spreadsheet, both on formative and summative tests, requires an internet connection.

Apart from the use of smartphones in schools which may tend to have a negative impact (Manumpil et al., 2015; Rahma, 2015), smartphones still have the opportunity to provide benefits in learning (Dewanti et al., 2016; Hochberg et al., 2018; Kuhn \& Vogt, 2015; Martono \& Nurhayati, 2014; Nanda \& Wilujeng, 2018). Moreover, with the increasing number and variety of assistance in learning that is possible to achieve using a smartphone. In the end, when students are accustomed to using smartphones as a means of supporting learning, they will begin to realize that smartphones provide benefits and facilities that facilitate learning activities so as to encourage them to explore their smartphones further (Woodcock et al., 2012).

\section{Disseminating Stage}

The dissemination stage is carried out by disseminating application products through possible platforms such as the Google Play Store. In addition, intellectual property rights in the form of a copyright certificate are also proposed for media products that have been developed.

\section{CONCLUSION}

Based on the development activities that have been carried out, an Android-based physics learning application is obtained which is named Interactive Physics Mobile Learning Media (IPMLM) Simple Harmonic Motion. Android-based IPMLM media on simple harmonic motion material is declared valid and suitable for use in learning physics. The IPMLM media assessment score is in the very good category. Limited testing with student respondents to assess the appearance and readability of the media also showed the results of the assessment in a good category. The product developed is then implemented in physics learning in high school. The implementation of Android-based IPMLM in physics learning with the instructional scaffolding approach is proven to increase the HOTS of students. The HOTS ability of students in the group that used the IPMLM media and the scaffolding learning approach experienced an increase in HOTS abilities with a better average. In addition, students who take part in learning using IPMLM media and the scaffolding learning approach also have higher achievement, as proven by the proportion of HOTS ability categories that are in the fair category or more are dominated by students who come from the experimental group. After all, the studies on this research were conducted in unusual conditions due to pandemic situations. Thus, it can be suggested to do further studies in scenarios where things have returned to normal with face-to-face learning.

\section{ACKNOWLEDGEMENT}

Researchers would like to thank the Directorate of Research and Community Service, Ministry of Research and Technology of the Republic of Indonesia for supporting research activities through the master thesis research funding program. 


\section{REFERENCES}

Agustihana, S., \& Suparno. (2018). Effectiveness of physics mobile learning media to improve higher order thinking skills of students in thermodynamics. Journal of Physics: Conference Series, 1097(1), 0-9.

Aiken, L. R. (1985). Three coefficients for analyzing the reliability and validity of ratings. Educational and Psychological Measurement, 45, 131-141.

Andi, H. J., \& Handayani, S. M. (2015). Pengaruh model pembelajaran GI dengan scaffolding terhadap penguasaan konsep fisika. Jurnal Pemikiran Penelitian Dan Sains Didaktika, 3(6), 159-169.

Anghileri, J. (2006). Scaffolding practices that enhance mathematics learning. Journal of Mathematics Teacher Education, 9(1), 33-52.

Anshari, M., Almunawar, M. N., Shahrill, M., Wicaksono, D. K., \& Huda, M. (2017). Smartphones usage in the classrooms: Learning aid or interference? Education and Information Technologies, 22(6), 3063-3079.

Arieputri, V. (2020). PAS: Pendidikan, arahan, dan sinergi menuju Indonesia emas. Jurnal Sentris, 1(1), 53-61.

Belland, B. R. (2017). Instructional Scaffolding in STEM Education Strategies and Efficacy Evidence. Springer International.

Brookhart, M. S. (2010). How To Assess Higher Order Thinking Skills in Your Classroom. ASCD.

Dewanti, T., Widada, W., \& Triyono, T. (2016). Hubungan antara keterampilan sosial dan penggunaan gadget smartphone terhadap prestasi belajar siswa SMA Negeri 9 Malang. Jurnal Kajian Bimbingan Dan Konseling, 1(3), 126-131.

González, M. Á., González, M. Á., Martín, M. E., Llamas, C., Martínez, Ó., Vegas, J., Herguedas, M., \& Hernández, C. (2015). Teaching and learning physics with smartphones. Journal of Cases on Information Technology, 17(1), 31-50.

Hambleton, R. K., Swaminathan, H., \& Rogers, H. J. (1991). Fundamentals of Item Response Theory Library. Sage Publication.

Helmi, F., Rokhmat, J., \& 'Ardhuha, J. (2017). Pengaruh pendekatan berpikir kausalitik ber-scaffolding tipe $2 \mathrm{~b}$ termodifikasi berbantuan LKS terhadap kemampuan pemecahan masalah fluida dinamis siswa. Jurnal Pendidikan Fisika dan Teknologi, III (1).

Herliandry, L. D., Nurhasanah, N., Suban, M. E., \& Kuswanto, H. (2020). Pembelajaran pada masa pandemi Covid-19. Jurnal Teknologi Pendidikan, 22(1), 65-70.

Hochberg, K., Kuhn, J., \& Müller, A. (2018). Using smartphones as experimental toolseffects on interest, curiosity, and learning in physics education. Journal of Science Education and Technology, 27(5), 385-403.

Kee, L. (2014). Mobile devices: Toys or learning tools for the 21 st century teenagers? The Turkish Online Journal of Educational Technology, 13(3), 107-122.

Kuhn, J., \& Vogt, P. (2015). Smartphones \& Co. in physics education: Effects of learning with new media experimental tools in acoustics. Multidisciplinary Research on Teaching and Learning, 253-269.

Lee, Y.-J. (2010). Developing a mobile physics learning environment based on physics misconception research and e-learning design principles. Journal of Computers in Mathematics and Science Teaching, 29(4), 399-416.

Lee, Y.-J. (2015). Developing ipad-based physics simulations that can help people learn newtonian physics concepts. Journal of Computers in Mathematics and Science Teaching, 34(3), 299-325. 
Lin, S. Y., \& Singh, C. (2015). Effect of scaffolding on helping introductory physics students solve quantitative problems involving strong alternative conceptions. Physical Review Special Topics - Physics Education Research, 11(2), 020105.

Manumpil, B., Ismanto, Y., \& Onibala, F. (2015). Hubungan penggunaan gadget dengan tingkat prestasi siswa di SMA Negeri 9 Manado. Ejoural Keperawatan (e-Kep), 3(2), $1-6$.

Mardiana, N., \& Kuswanto, H. (2017). Android-assisted physics mobile learning to improve senior high school students' divergent thinking skills and physics HOTS. AIP Conference Proceedings, 1868(August).

Martono, K. T., \& Nurhayati, O. D. (2014). Implementation of android based mobile learning apllication as a flexible learning media. International Journal of Computer Science Issues, 11(3), 168-174.

Maryati, S. (2015). Dinamika pengangguran terdidik: Tantangan menuju bonus demografi di Indonesia. Economica, 3(2), 124-136.

Matsun, M., Ramadhani, D., \& Lestari, I. (2018). Perancangan media pembelajaran listrik magnet berbasis android di program studi pendidikan fisika IKIP PGRI Pontianak. Jurnal Pendidikan Informatika Dan Sains, 7(1), 107-117.

Nanda, O. A., \& Wilujeng, I. (2018). The effectiveness of android-assisted optical devices learning to improve students' conceptual understanding. Jurnal Penelitian Dan Pembelajaran IPA, 4(2).

Nisrina, N., Gunawan, G., \& Harjono, A. (2018). Pembelajaran kooperatif dengan media virtual untuk peningkatan penguasaan konsep fluida statis siswa. Jurnal Pendidikan Fisika Dan Teknologi, 2(2).

Nofrion, N., \& Wijayanto, B. (2018). Learning activities in higher order thinking skill (HOTS) oriented learning context. Geosfera Indonesia, 3(2), 122.

OECD. (2016). PISA 2015 Results (Volume I): Excellence and Equity in Education. https://doi.org/https://doi.org/10.1787/9789264266490-en

Oprea, M., \& Miron, C. (2014). Mobile phones in the modern teaching of physics. Romanian Reports in Physics, 66(4), 1236-1252.

P21: Partnership for 21st Century Learning. (2007). Framework for 21st Century Learning - P21. P21.Org. http://www.p21.org/our-work/p21-framework

Rahma, A. (2015). The influence of using smartphone in the students activities (the problems of MAN 1 Rangat Barat). Jurnal Fisip, 2(2), 1-12.

Ramos, J. L. S., Dolipas, B. B., \& Villamor, B. B. (2013). Higher order thinking skills and academic performance in physics of college students: A regression analysis. Bulletin of the Museum Society of Maidugur, 4(4), 7-48.

Retnawati, H., Djidu, H., Kartianom, Apino, E., \& Anazifa, R. D. (2018). Teachers' knowledge about higher-order thinking skills and its learning strategy. Problem of Education in the 21st Century, 76(2), 215-230.

Rusli, M. A., Prabowo, Widodo, W., \& Usman. (2014). Pembelajaran fisika melalui pemrosesan top down berbasis scaffolding untuk melatihkan keterampilan berpikir kritis physics learning through top down processing based on scaffolding to train critical thinking skills. Jurnal Sainsmart, III(1), 1-11.

Saman, M. I., Koes H, S., \& Sunaryono. (2017). E-Scaffolding untuk meningkatkan kemampuan pemecahan masalah fisika. Pros. Seminar Pend. IPA Pascasarjana UM, $2,219-225$.

Santrock, J. W. (2017). Educational Psychology. McGraw-Hill.

Schunk, D. H. (2011). Learning Theories: an educational perspective. Pearson.

Slavin, R. E. (2017). Educational Psychology: theory and practice. Pearson. 
Subandowo, M. (2017). Peradaban dan produktivitas dalam perspektif bonus demografi serta generasi Y dan Z. Sosiohumanika: Jurnal Pendidikan Sains Sosial Dan Kemanusiaan, 10(November), 191-208.

Tanujaya, B., Mumu, J., \& Margono, G. (2017). The relationship between higher order thinking skills and academic performance of student in mathematics instruction. International Education Studies, 10(11), 78.

Taufik, M., \& Kristanto, A. (2018). Pengembangan mobile learning berbasis aplikasi android mata pelajaran fisika materi listrik arus searah kelas XI SMK Negeri 2 Kediri. Jurnal Mahasiswa Teknologi Pendidikan, 9(2), 1-8.

Taufiq, M., Amalia, A. V., Parmin, P., \& Leviana, A. (2016). Design of science mobile learning of eclipse phenomena with conservation insight android-based app inventor 2. Jurnal Pendidikan IPA Indonesia, 5(2), 291-298.

Thiagarajan, S., Semmel, D. S., \& Semmel, M. I. (1974). Instructional development for training teachers of expectional children. Leadership Training Institute/Special Education, University of Minnesota.

Tossell, C. C., Kortum, P., Shepard, C., Rahmati, A., \& Zhong, L. (2015). You can lead a horse to water but you cannot make him learn: Smartphone use in higher education. British Journal of Educational Technology, 46(4), 713-724.

Urban-woldron, H. (2009). Interactive Simulations for the effective learning of physics. Journal of Computers in Mathematics \& Science Teaching, 28(2), 163-176.

Voogt, J., \& Roblin, N. P. (2012). A comparative analysis of international frameworks for 21stcentury competences: Implications for national curriculum policies. Journal of Curriculum Studies, 44(3), 299-321.

WIPO. (2019). The Global Innovation Index 2019: Creating Healthy Lives-The Future of Medical Innovation.

Woodcock, B., Middleton, A., \& Nortcliffe, A. (2012). Considering the smartphone learner: Developing innovation to investigate the opportunities for students and their interest. Student Engagement and Experience Journal, 1(1), 1-15.

Yi, Y. J., You, S., \& Bae, B. J. (2016). The influence of smartphones on academic performance: The development of the technology-to-performance chain model. Library Hi Tech, 34(3), 480-499.

Zahid, M. Z. (2018). Aplikasi berbasis android untuk pembelajaran: Potensi dan metode pengembangan. PRISMA. Prosiding Seminar Nasional Matematika, 1, 910-918. 